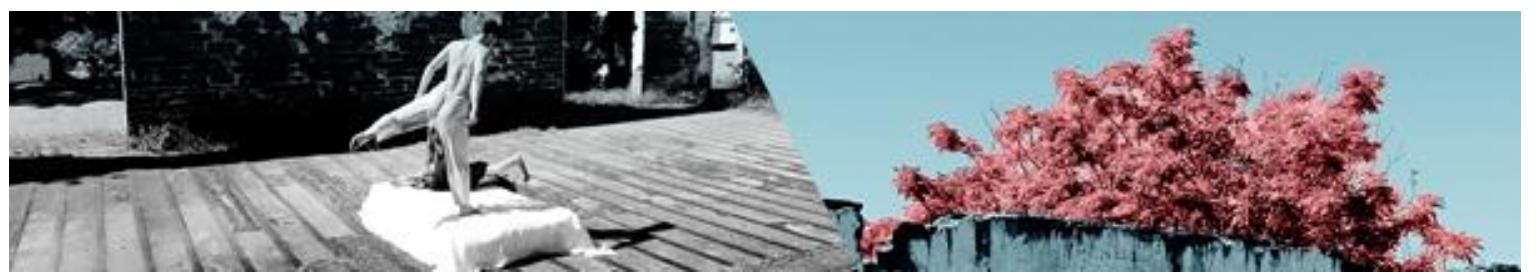

\title{
ENTRE O PENSAR E O SENTIR: INVESTIGAÇÕES SOBRE A INFLUÊNCIA DA RESPIRAÇÃO NA FORMAÇÃO TÉCNICO- ARTÍSTICA DO BAILARINO CONTEMPORÂNEO
}

Silvia Maria Geraldi ${ }^{1}$ Julia Ferreira ${ }^{2}$

Resumo: Essa comunicação é resultado de uma pesquisa prático-teórica que teve como foco a investigação da respiração na relação com o corpo que dança. O estudo partiu de indagações a respeito das influências exercidas pela respiração na aprendizagem técnico-artística da(o) bailarina(o) contemporânea(o), investigando em que medida esta pode facilitar a organização postural e expandir a consciência cinética. Fundamentando-se em abordagens da educação somática, sobretudo no Método Feldenkrais, o processo de pesquisa e a análise dos resultados buscaram articular três eixos: a compilação de estudiosos que tratam do tema, os laboratórios práticos para entendimento no corpo e o entrelaçamento entre teoria e prática.

Palavras-chave: Respiração; Educação somática; Dança contemporânea.

\section{BETWEEN THINKING AND FEELING: INVESTIGATIONS ABOUT THE INFLUENCE OF BREATHING IN THE TECHNICAL-ARTISTIC TRAINING OF THE CONTEMPORARY DANCER}

\begin{abstract}
This communication is the result of practical-theoretical research that focused on the investigation of breathing in relation to the dancing body. The study was based on inquiries about the influences of breathing in the technical-artistic learning process of the contemporary dancer, investigating to what extent it can facilitate the postural organization and expand the kinetic awareness. Supported by somatic education approaches, especially the Feldenkrais Method, the research process and the analysis of the results sought to articulate three axes: the compilation of scholars that deal with the subject, the practical laboratories for understanding in the body and the interweaving of theory and practice.
\end{abstract}

Keywords: Breathing; Somatic education; Contemporary dance.

\footnotetext{
${ }^{1}$ Silvia Maria Geraldi - Artista, professora e pesquisadora da dança. Docente do Departamento de Artes Corporais, Instituto de Artes, UNICAMP. É também professora do Programa de Pós-Graduação em Artes da Cena na mesma instituição, atuando como coordenadora dentro do biênio 2017-2019. Lidera o Grupo "Prática como pesquisa: processos de produção da cena contemporânea" (CNPq). Certificada como professora e instrutora do Método Feldenkrais de Educação Somática. Autora do livro "Raízes da Teatralidade na Dança Paulistana, duas criadoras" (Editora Prismas, 2015).

2 Júlia Ferreira - Bacharela (2016) e Licenciada (2017) em Dança pela Universidade Estadual de Campinas. Integrou a organização do FEIA - Festival do Instituto de Artes da UNICAMP (2013-2015). Estagiou no Grupo Dançaberta (Campinas, SP, 2014), onde atualmente atua como bailarina e integra a equipe de produção executiva. Desenvolveu projeto de Iniciação Científica financiado pela FAPESP (2015-2017) e contemplado com o Prêmio Mérito Científico no XXIV Congresso de Iniciação Científica da Unicamp (2016) e como o melhor trabalho na área de Artes no 69 ${ }^{a}$ Reunião Anual da SBPC (2017).
}

GERALDI, Silvia Maria; FERREIRA, Julia. Entre o pensar e o sentir: investigações sobre a influência da respiração na formação técnico-artística do bailarino contemporâneo. Revista da FUNDARTE, Montenegro, p.243-261, ano 19, no 37, Janeiro/Março.

Disponível em: http://.seer.fundarte.rs.gov.br/index.php/RevistadaFundarte/index> 30 de março de 2019. 


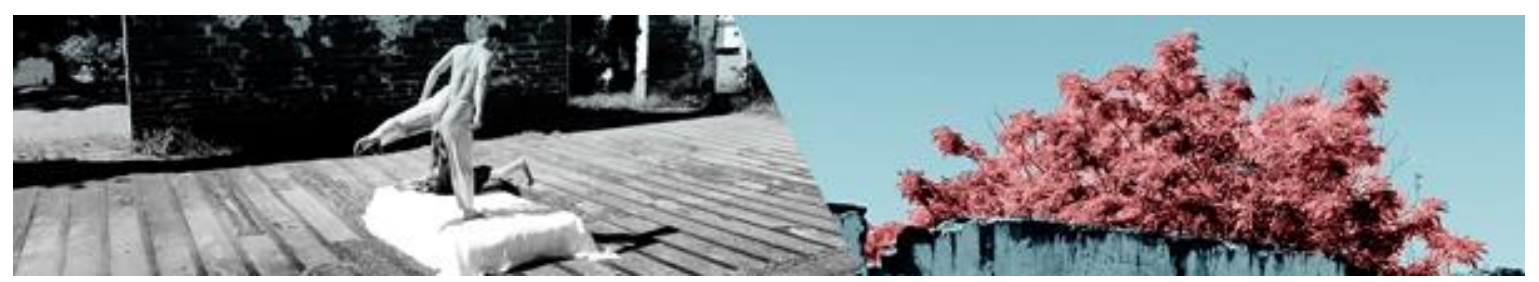

\section{Consciência respiratória e corporeidade dançante}

$\mathrm{O}$ ato de respirar tem ocupado a história da dança de forma relativamente insistente, seja para caracterizar diferentes abordagens à fisicalidade, para investigar modelos renovados de treinamento do corpo ou para desvelar expressividades ímpares. A exemplo disso, os movimentos da dança moderna americana e centro-europeia foram profícuos na invenção de técnicas nas quais a respiração assumiu papel preponderante, com impactos sensíveis sobre o pensamento, a poética e o ensino contemporâneos da dança.

Foi do interesse suscitado pelo tema da respiração na relação com o movimento dançado que nasceu a pesquisa intitulada "Entre o corpo e o papel: investigação sobre a influência da respiração na formação técnico-artística do bailarino contemporâneo"3. Desenvolvida como uma Iniciação Científica dentro do curso de graduação em Dança da Unicamp, a investigação se deu entre os anos de 2015 e 2017, recebendo Bolsa da Fundação de Amparo à Pesquisa do Estado de São Paulo (Fapesp) para o seu desenvolvimento integral ${ }^{4}$.

O elemento disparador da pesquisa proveio das experiências pessoais da pesquisadora/estudante em práticas de dança realizadas antes e após seu ingresso na universidade. Sua trajetória foi iniciada ainda criança através de aulas de balé clássico, desdobrando-se posteriormente por outras experiências (jazz, sapateado e contemporâneo), todas vivenciadas numa mesma academia em sua cidade de origem, na qual permaneceu até sua entrada no ensino superior em 2012. Embora nas aulas houvesse uma preocupação com a postura do aluno, pouco ou nada se falava a respeito da importância do trabalho respiratório para a organização do corpo que dança, a não ser como mera necessidade fisiológica de oxigenação corporal. Já nas práticas da graduação, era evidente o destaque dado à respiração, em abordagens múltiplas e diferenciadas, que auxiliavam na transformação das

\footnotetext{
${ }^{3}$ Título original da pesquisa, que sofreu pequena alteração ao nomear o presente artigo.

${ }^{4}$ Destaca-se que a pesquisa recebeu também o Prêmio Mérito Científico, em novembro de 2016, no XXIV Congresso de Iniciação Científica da Unicamp, promovido pela Pró-Reitoria de Pesquisa; e foi contemplada como o Melhor Trabalho da Área de Artes na 69a. Reunião Anual da Sociedade Brasileira para o Progresso da Ciência (SBPC), ocorrida na Universidade Federal de Minas Gerais (UFMG) em julho de 2017.
}

GERALDI, Silvia Maria; FERREIRA, Julia. Entre o pensar e o sentir: investigações sobre a influência da respiração na formação técnico-artística do bailarino contemporâneo. Revista da FUNDARTE, Montenegro, p.243-261, ano 19, oㅜ 37, Janeiro/Março.

Disponível em: http://.seer.fundarte.rs.gov.br/index.php/RevistadaFundarte/index> 30 de março de 2019. 


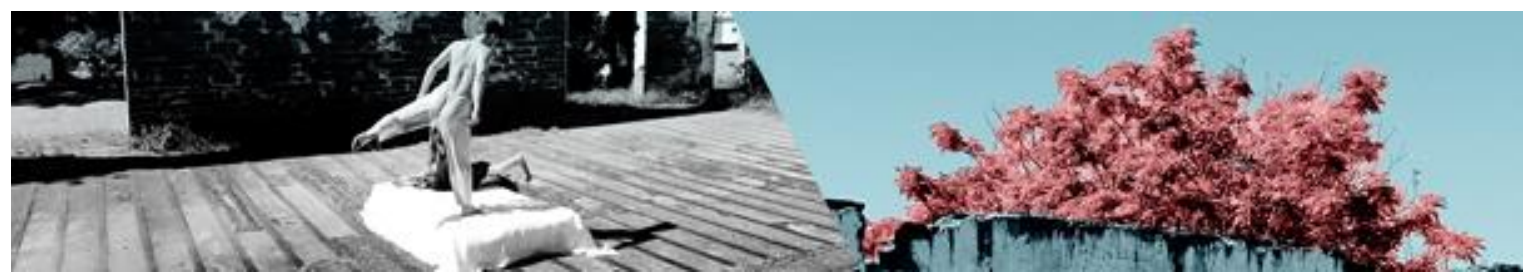

qualidades técnicas e expressivas do corpo e, principalmente, na conquista (sensível e visível) de uma melhor reorganização postural.

Ainda, o contato com o Método Feldenkrais de Educação Somática, vivenciado em aulas da graduação e/ou por meio de leituras como "Solte-se" (ZEMACH-BERSIN; ZEMACH-BERSIN; REESE, 1992) e "Consciência pelo Movimento" (FELDENKRAIS, 1977), despertaram curiosidade crescente a respeito da relação entre a respiração e o corpo dançante, ao mesmo tempo em que desvelaram o papel primordial que a consciência respiratória tem para o estudo do movimento e de seus aspectos qualitativos (peso, fluência, mobilidade, tônus, aceleração, etc.).

É importante destacar a relação intrínseca entre o percurso da dança contemporânea e a utilização de técnicas de inteligência do movimento (LOUPPE, 2012), voltadas ao conhecimento e compreensão do eu-corpo. Seja qual for o viés da aprendizagem - técnico, criativo, expressivo -, a respiração resulta em ferramenta poderosa e indispensável para acercar-se do instigante "laboratório de percepção" que é a corporeidade dançante, conforme nos relembra a historiadora Annie Suquet:

\begin{abstract}
A escuta dos ritmos fisiológicos desempenha nesta perspectiva um papel preponderante desde o início da dança moderna. [...] 'Ouçamos as batidas de nosso coração, o sussurrar e o murmurejar de nosso próprio sangue', preconiza Mary Wigman, pioneira da moderna dança alemã. Quanto à respiração, é ela que 'comanda silenciosamente as funções musculares e articulares', continua a bailarina. Da mesma forma, a amplitude e a velocidade dos movimentos do bailarino são o efeito da 'potência dinâmica do fôlego que se revela no grau de intensidade e de tensão do momento'. O alternar-se da inspiração e da expiração fornece aos bailarinos a matriz dos princípios de tensão/relaxamento, com a promessa de múltiplas interpretações e evoluções ao longo de todo o século XX. (SUQUET, 2008, p. 513).
\end{abstract}

Diante da imensa gama de técnicas que poderiam ter sido acolhidas para investigar a relação entre respiração e organização postural no movimento dançado, fez-se necessário um recorte, optando-se pelo trabalho somático desenvolvido por Moshe Feldenkrais (1904-1984), comumente conhecido como Consciência pelo

GERALDI, Silvia Maria; FERREIRA, Julia. Entre o pensar e o sentir: investigações sobre a influência da respiração na formação técnico-artística do bailarino contemporâneo. Revista da FUNDARTE, Montenegro, p.243-261, ano 19, no 37, Janeiro/Março.

Disponível em: http://.seer.fundarte.rs.gov.br/index.php/RevistadaFundarte/index> 30 de março de 2019. 


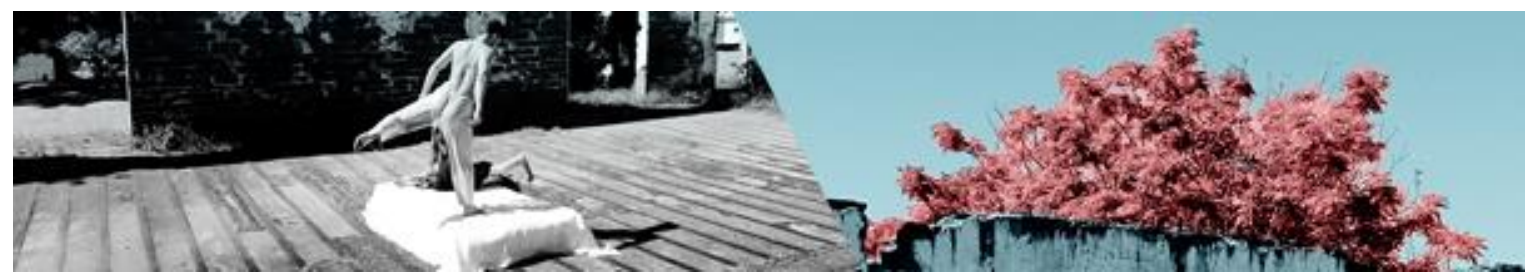

Movimento ${ }^{5}$. A escolha fundamentou-se na experiência prévia e significativa que a pesquisadora/estudante teve com o método durante cerca de um ano, dentro das aulas técnicas de dança na universidade, ministradas pela professora/orientadora dessa pesquisa. Do conhecimento vivenciado no corpo, surgiu a vontade de investigar mais a fundo a integração dos saberes somáticos, sobretudo o Método Feldenkrais, com as técnicas de dança contemporânea em estudo, tendo como recorte específico a respiração, seus processos e qualidades, em relação aos aspectos dinâmicos da postura.

\section{Desenho de pesquisa}

O processo de pesquisa foi, desde o princípio, guiado pela prática, isto é, teve como ponto de partida as experiências vivenciadas diretamente no corpo da pesquisadora/estudante. Nesse tipo de abordagem metodológica, o conhecimento sensível-corporal é prioritário e, geralmente, é a partir dele que as perguntas, problemas, desafios são identificados, desenvolvidos e contestados. Além disso, o intuito foi elaborar um desenho de pesquisa que se aproximasse o mais possível do pensamento/prática somáticos, no qual a conceituação e discussão teórica fossem construídas a partir do processo prático.

Essa escolha encontrou fundamentação nas reflexões de Sylvie Fortin (2010) acerca das possíveis contribuições da etnografia e da autoetnografia para a pesquisa na prática artística. A autora parte da premissa que uma melhor compreensão da prática artística no contexto acadêmico pode se dar através do vínculo entre o pensamento e a ação do praticante. Ela afirma que a etnografia e a autoetnografia podem ser consideradas como métodos de pesquisa apropriados para lidar com processos artísticos, em quaisquer espaços onde estes ocorram: no estúdio, no atelier, na aula ou na comunidade; e que podem, inclusive, inspirar uma "bricolagem" metodológica, tomando de empréstimo elementos vindos de cenários metodológicos variados, sem que isso se configure em síntese aleatória, carente de

\footnotetext{
${ }^{5}$ Moshe Feldenkrais (1904-1984) foi matemático, engenheiro e físico israelense, criador do método que leva seu nome. O Método Feldenkrais de Educação Somática possui dois procedimentos básicos de trabalho: Consciência pelo Movimento (Awareness Through Movement), destinado a sessões grupais; e Integração Funcional (Functional Integration) para as sessões individuais.
}

GERALDI, Silvia Maria; FERREIRA, Julia. Entre o pensar e o sentir: investigações sobre a influência da respiração na formação técnico-artística do bailarino contemporâneo. Revista da FUNDARTE, Montenegro, p.243-261, ano 19, ํo 37, Janeiro/Março.

Disponível em: http://.seer.fundarte.rs.gov.br/index.php/RevistadaFundarte/index> 30 de março de 2019. 


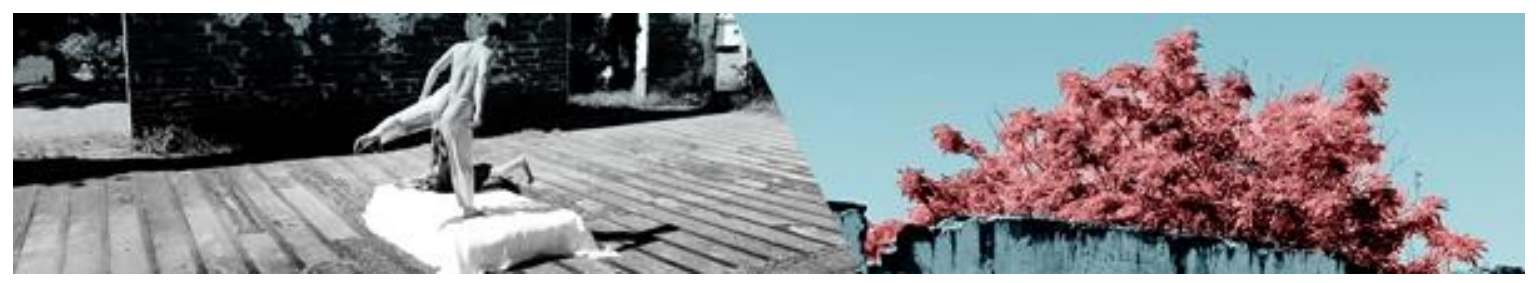

rigor e de reflexão. Sob essa perspectiva, o pesquisador em prática artística, ao debruçar-se sobre seu campo de pesquisa, pode coletar/produzir dados etnográficos sem necessariamente realizar uma etnografia.

Pesquisas artísticas, como a aqui enfocada, exigem processos investigativos que articulem constantemente leituras de textos à experiência prática. Outra particularidade é o fato da teorização tomar quase sempre a forma de uma análise reflexiva sobre a prática (FORTIN, 2010). Por isso, três eixos estiveram em permanente articulação durante o percurso da pesquisa: o primeiro foram os laboratórios práticos individuais baseados em experiências realizadas no corpo da pesquisadora/estudante; o segundo, a compilação de estudiosos do movimento que trataram/tratam sobre o tema da respiração; e a terceira, a conceituação com foco no entrelaçamento entre a teoria e a prática.

A pesquisa histórica foi, desde a elaboração do projeto, um elemento-chave. Iniciada a partir das correntes modernas da dança, ela teve grande importância para o entendimento das heranças deixadas por artistas diversos, criadores de técnicas respiratórias que exerceram influência marcante em sucessivas gerações de bailarinos. Passando por Émile Jaques-Dalcroze, Isadora Duncan, Martha Graham, Mary Wigman, Doris Humphrey e tantos outros, o estudo de diferentes fontes históricas ajudou a elucidar certos usos que treinamentos contemporâneos de dança têm feito da respiração.

Dos vínculos entre trabalho prático e pesquisa teórica, surgiram as seguintes perguntas norteadoras: Em que medida pode-se modificar o estado de consciência do corpo que dança a partir de um trabalho sistemático de reeducação da respiração? Qual a relação entre respiração e postura corporal e quais seus efeitos na corporeidade dançante?

Mais que fornecer respostas conclusivas às questões levantadas, a intenção prioritária foi produzir experiências significativas para a pesquisadora/estudante, orientadas para uma aprendizagem ou tomada de consciência através do movimento. É relevante destacar que o movimento é o meio - e não o fim - dentro do trabalho de Feldenkrais. Embora o método possa provocar mudanças no modo como as pessoas se movem, o que está em questão é a dinâmica processual de

GERALDI, Silvia Maria; FERREIRA, Julia. Entre o pensar e o sentir: investigações sobre a influência da respiração na formação técnico-artística do bailarino contemporâneo. Revista da FUNDARTE, Montenegro, p.243-261, ano 19, ํo 37, Janeiro/Março.

Disponível em: http://.seer.fundarte.rs.gov.br/index.php/RevistadaFundarte/index> 30 de março de 2019. 


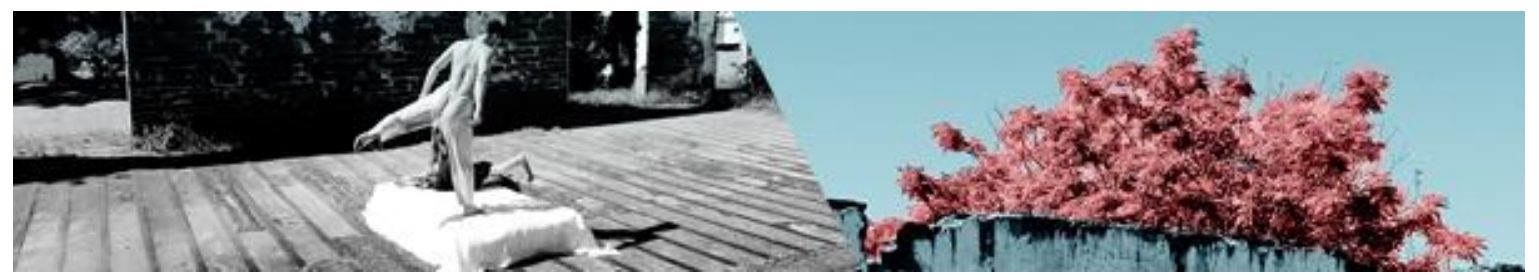

autoconhecimento voltada para o refinamento da percepção, da qualidade de atenção e do espírito exploratório do praticante. Segundo seu criador, "A vida do Homem é um processo contínuo e a melhora necessária está na qualidade do processo, e não nas propriedades ou disposição. Quanto mais são entendidos os fundamentos do processo, maiores serão as realizações" (FELDENKRAIS, 1977, p. 52, grifo nosso).

Os materiais levados para os laboratórios foram resgatados de diferentes técnicas de dança contemporânea vivenciadas na graduação pela pesquisadora/estudante, sendo selecionados de acordo com a ênfase na relação entre respiração e comportamento sensório-motor. A estes, somaram-se exercícios pertencentes à literatura de Moshe Feldenkrais, publicada em Língua Portuguesa, em especial as obras "Consciência pelo Movimento" (1977) e "O poder da autotransformação" (1994), além do livro "Solte-se" (1992), cujos autores estão entre seus primeiros alunos. O pensamento/ação praticado nos laboratórios permitiu não somente o estudo e aprofundamento prático-conceitual das matrizes de movimento, como a criação de novas combinações.

O processo de pesquisa foi se moldando como conjuntos de práticas de acordo com recortes distintos efetuados sobre o tema. Levando-se em consideração a grande quantidade de material prático e teórico produzido pela pesquisa, apenas parte dos resultados será apresentada a seguir, denominada de Experiência Um e Experiência Dois. Dentro de cada Experiência, o leitor poderá ter acesso aos principais conteúdos e procedimentos desenvolvidos, seguidos de breve análise sobre processo e resultados.

\section{Experiência Um: o encontro com a técnica}

No capítulo 15 do livro "O poder da autotransformação" (1994), Feldenkrais se debruça inicialmente sobre a técnica por ele desenvolvida, dando ênfase a não separação da unidade funcional formada por corpo, mente e ambiente. Para ele, a principal característica da técnica é lidar por inteiro com a reeducação dessa relação, tornando viável seu funcionamento em todos os níveis. Tomando o exemplo prático da respiração, Feldenkrais (1994, p. 152) examina como se dá "o

GERALDI, Silvia Maria; FERREIRA, Julia. Entre o pensar e o sentir: investigações sobre a influência da respiração na formação técnico-artística do bailarino contemporâneo. Revista da FUNDARTE, Montenegro, p.243-261, ano 19, ํo 37, Janeiro/Março.

Disponível em: http://.seer.fundarte.rs.gov.br/index.php/RevistadaFundarte/index> 30 de março de 2019. 


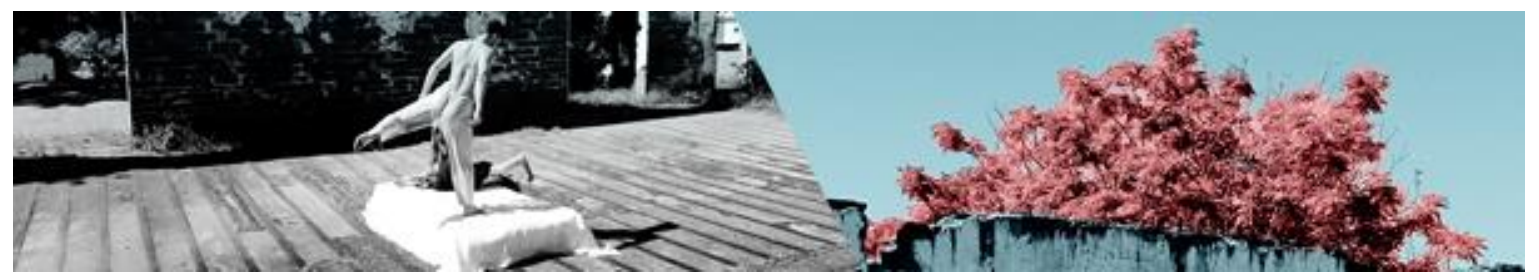

aprendizado de um modo de agir mais adequado", que tem no próprio sistema de ação corporal sua forma direta de conhecimento:

Assim, não ensinamos a maneira correta de respirar, mas todas as formas possíveis de respiração. Não ensinamos as pessoas a manter o estômago contraído e plano, mas toda a variedade de contrações abdominais, desde a expansão até o completo esvaziamento da cavidade abdominal, como na ioga. $O$ mesmo é verdadeiro com relação à pélvis, à cabeça e todas as articulações do corpo. O efeito final é que, em cada situação, a estrutura ajusta-se da melhor maneira possível, porque nos tornamos conscientes das contrações parasitas mantidas sem nenhum objetivo [...]. (FELDENKRAIS, 1994, p. 152, grifo do autor).

O método age no sentido de intensificar a comunicação entre o sistema nervoso e os músculos, utilizando como ferramentas a qualidade de atenção na ação realizada e a exploração dos padrões neuromusculares. Feldenkrais explica que, através de uma mudança fundamental na base motora e, portanto, no córtex motor, é possível quebrar a coesão dos padrões familiares preexistentes. Nessas condições, o hábito se torna mais acessível a mudanças, podendo ocorrer 0 aperfeiçoamento da própria capacidade de aprender.

O autor propõe, no mesmo capítulo, uma série de experiências práticas ao leitor para que o mesmo possa colocar em exame os princípios técnicos recém apresentados. Como o movimento respiratório assume um papel fundamental nos exemplos práticos propostos, este pareceu ser um ponto de partida interessante para se investigar a primeira pergunta norteadora da pesquisa: o impacto que a reeducação da respiração tem no estado de consciência do corpo que dança.

Estado de consciência é uma noção aqui definida com base nos estudos somáticos desenvolvidos por Moshe Feldenkrais e alguns de seus seguidores. Estudiosos recentes de seu trabalho vêm destacando a necessidade de revisão de algumas terminologias que se tornaram lugares comuns nos discursos e práticas de alunos e professores do método. Consciência está entre as palavras que têm recebido atenção especial e despertado diferentes entendimentos.

As sessões grupais do método, originalmente denominadas por seu criador de Awareness through Movement, foram traduzidas em Língua Portuguesa por

GERALDI, Silvia Maria; FERREIRA, Julia. Entre o pensar e o sentir: investigações sobre a influência da respiração na formação técnico-artística do bailarino contemporâneo. Revista da FUNDARTE, Montenegro, p.243-261, ano 19, ํo 37, Janeiro/Março.

Disponível em: http://.seer.fundarte.rs.gov.br/index.php/RevistadaFundarte/index> 30 de março de 2019. 


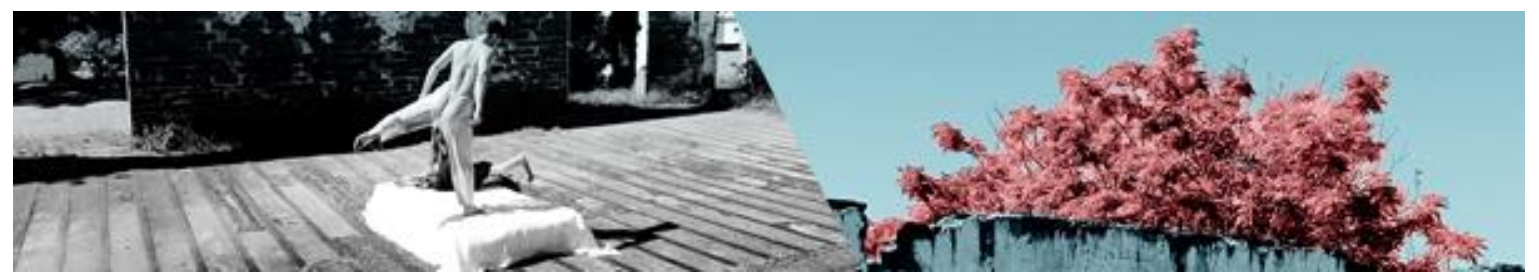

Consciência pelo Movimento. Do mesmo modo, Marie Bardet (2015) nos informa que a expressão em francês é habitualmente conhecida por tomada de consciência pelo movimento. Fazendo uma distinção entre awareness e consciouness, a autora propõe um deslocamento terminológico, substituindo awareness por atenção. Ela argumenta que o Método Feldenkrais não procura trabalhar sobre o corpo do indivíduo, desenvolvendo uma consciência de algo (corpo-objeto-físico). O trabalho se dá sobre certa concepção de atenção: a atenção através do movimento. A esse respeito, o próprio Feldenkrais afirma que o método opera mais com base em relações do que sobre o corpo como algo separado e único. Essas relações se dão de forma múltipla e envolvem o esqueleto, os músculos, o sistema nervoso e o meio ambiente. Portanto, a atenção através do movimento é mais uma atenção a uma relação variável e dinâmica entre diferentes elementos do que uma tomada de consciência do corpo físico (BARDET, 2015).

Os exercícios apresentados no capítulo 15 configuraram-se, de início, como um microuniverso de treinamento e reflexão sobre essa qualidade distintiva de atenção. Organizados em sessões, cada uma contendo um conjunto de instruções práticas comentadas pelo autor e intercaladas por pausas para observação das alterações resultantes (scanning), os exercícios buscam explorar os limites mais amplos da função de flexão da coluna vertebral. O objetivo é proporcionar ao praticante o aprendizado de como ele se sente quando diminui a contração dos músculos extensores. Eles consistem na inversão do corpo (da relação cabeça/cóccix) na posição deitada, na qual a maior parte das costas e a cabeça ficam apoiadas no chão, a bacia e as pernas ficam aéreas, enquanto os pés são levados para trás da cabeça (ver Figura 1).

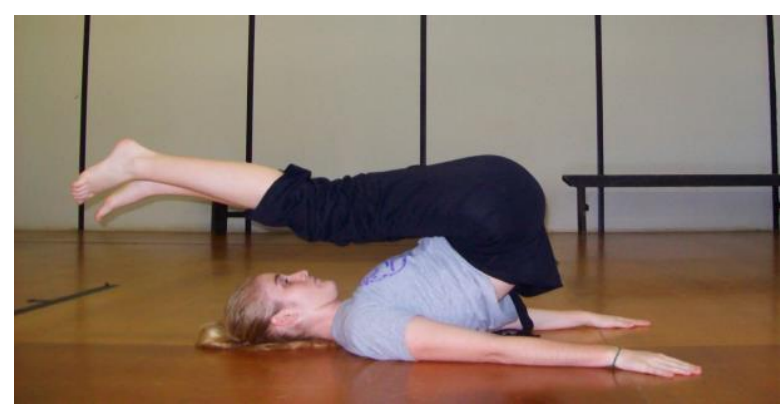

Figura 1 - Acervo pessoal

GERALDI, Silvia Maria; FERREIRA, Julia. Entre o pensar e o sentir: investigações sobre a influência da respiração na formação técnico-artística do bailarino contemporâneo. Revista da FUNDARTE, Montenegro, p.243-261, ano 19, ํo 37, Janeiro/Março.

Disponível em: http://.seer.fundarte.rs.gov.br/index.php/RevistadaFundarte/index> 30 de março de 2019. 


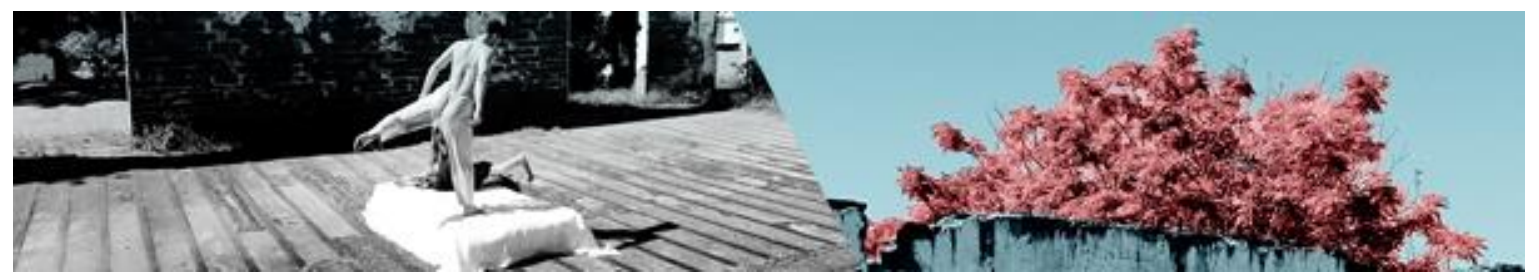

A partir desta posição, são propostas instruções variadas de movimento, desde a simples respiração até os rolamentos da posição sentada para a inicial. A respiração tem aqui um importante papel na organização da ação dos extensores da coluna. Além disso, ela pode ser utilizada como recurso de verificação, ajudando o praticante a identificar quando esforços supérfluos acontecem (por exemplo, prender a respiração) e, assim, corrigir a ação.

Ao exercício anterior, conjugou-se uma segunda lição baseada no método, conhecida como Respiração Total, que integra o livro "Solte-se" (1992) - uma introdução aos exercícios neuromusculares desenvolvidos por Feldenkrais. A partir dela, foi possível entrar em contato com dois padrões básicos da respiração humana: a respiração diafragmática e a respiração paradoxal. $\mathrm{Na}$ respiração diafragmática, o abdômen se expande na realização da inspiração, retornando ao estado normal na expiração; ao passo que na respiração paradoxal, o tórax se expande na inspiração com consequente recolhimento do abdômen, invertendo-se esse movimento na expiração. Além da ampliação da capacidade pulmonar e do alcance de uma qualidade respiratória mais rítmica e sem esforço, o exercício propicia a diferenciação gradativa das partes e funções envolvidas na respiração, com impactos perceptíveis na organização postural ao final do trabalho.

Os estudos somáticos em laboratório assumiram, nessa pesquisa, um papel de aprofundamento da dança somaticamente ensinada na graduação da Unicamp; e, embora essa última valorize a experiência sensorial como parte do aprendizado técnico-expressivo, os objetivos formativos estão dirigidos à qualificação do bailarino contemporâneo, exigindo ferramentas que extrapolem o campo do sensível. Além disso, o interesse da pesquisadora/estudante passou a se dirigir, cada vez mais, para uma crescente integração entre os dois universos dentro dos laboratórios práticos.

Da dança foram recuperadas duas matrizes de movimento, aprendidas com professoras diferentes dentro do percurso da graduação, nas quais a tônica era a integração entre respiração e movimento. Um elemento comum às matrizes era seu enraizamento em princípios técnicos ligados à dança moderna americana. Por esse motivo, a respiração representava, em ambas, um importante dispositivo de controle

GERALDI, Silvia Maria; FERREIRA, Julia. Entre o pensar e o sentir: investigações sobre a influência da respiração na formação técnico-artística do bailarino contemporâneo. Revista da FUNDARTE, Montenegro, p.243-261, ano 19, ํo 37, Janeiro/Março.

Disponível em: http://.seer.fundarte.rs.gov.br/index.php/RevistadaFundarte/index> 30 de março de 2019. 


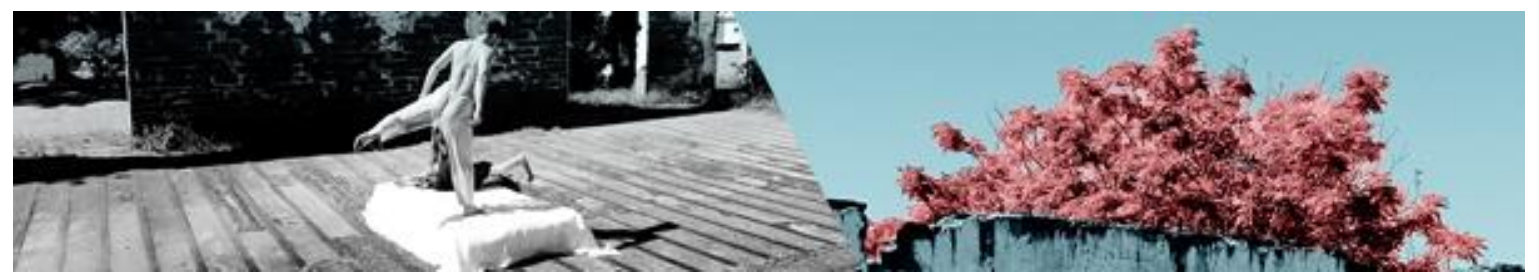

e modulação das funções musculares e articulares. Sabe-se que é principalmente com a primeira geração de bailarinos modernos que a respiração aparece como um meio de atingir lugares corporais ainda não muito familiares:

A teoria de Delsarte foi extremamente influente na primeira geração de bailarinos modernos, principalmente disseminada por Genevieve Stebbins (1857-1914), que reuniu ideias de Delsarte e exercícios planejados por James Steele MacKaye (professor norte americano de Delsarte), combinando técnicas de respiração que enfocavam primeiramente atitudes e gestos, realizados enquanto se está no lugar. (CAVRELL, 2012, p. 86-87).

Ocupando inicialmente um ponto fixo no espaço, a primeira matriz investigada inicia-se em pé e consiste em levar a respiração para três partes específicas do corpo - abdômen, peito e base da cabeça - com o suporte das mãos. Trabalha-se a maleabilidade do tronco em sintonia com a respiração, articulando conscientemente os espaços entre as vértebras e buscando a soltura da parte superior do corpo sobre os apoios dos pés. O objetivo é explorar horizontalmente todo o espaço em volta, mas sem perder o eixo vertical, necessário para manter-se em pé. Já o segundo estudo é uma atividade sentada que envolve a flexibilidade da coluna em resposta ao ritmo da respiração. Envolve a realização de contractions e releases do tronco em coordenação com a expiração e inspiração, respectivamente. A ação dos braços também acontece de forma associada, dirigindo-se à frente quando o corpo se contrai e ao alto quando se expande (ver Figura 2).

Destaca-se que as professoras, inspiradoras das referências acima, tiveram sua formação intimamente ligada ao estudo das técnicas de Graham e HumphreyLimón, sendo possível notar, como parte dessa influência, a importância que a respiração assume junto à execução do movimento em suas aulas. Conforme esclarece Patrícia Leal (2000), Martha Graham desenvolveu sua técnica a partir da ação essencial do ato de respirar, relacionando-o com a funcionalidade corporal em relação à expiração e inspiração: o expirar levando à contração (contraction) e o inspirar à expansão do corpo (release). Como resultado da conexão entre respiração e movimento, o trabalho muscular se dá com uma tensão adequada, otimizando a atividade realizada. Pensando-se ainda no suporte interno, o movimento respiratório

GERALDI, Silvia Maria; FERREIRA, Julia. Entre o pensar e o sentir: investigações sobre a influência da respiração na formação técnico-artística do bailarino contemporâneo. Revista da FUNDARTE, Montenegro, p.243-261, ano 19, ํo 37, Janeiro/Março.

Disponível em: http://.seer.fundarte.rs.gov.br/index.php/RevistadaFundarte/index> 30 de março de 2019. 


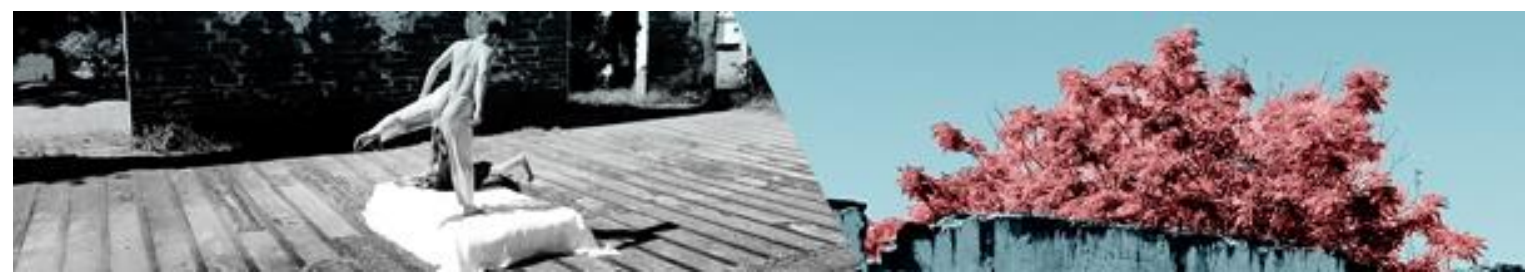

encontra-se fortemente ligado à coluna que, unindo a caixa torácica à bacia, cria uma conexão do corpo inteiro.

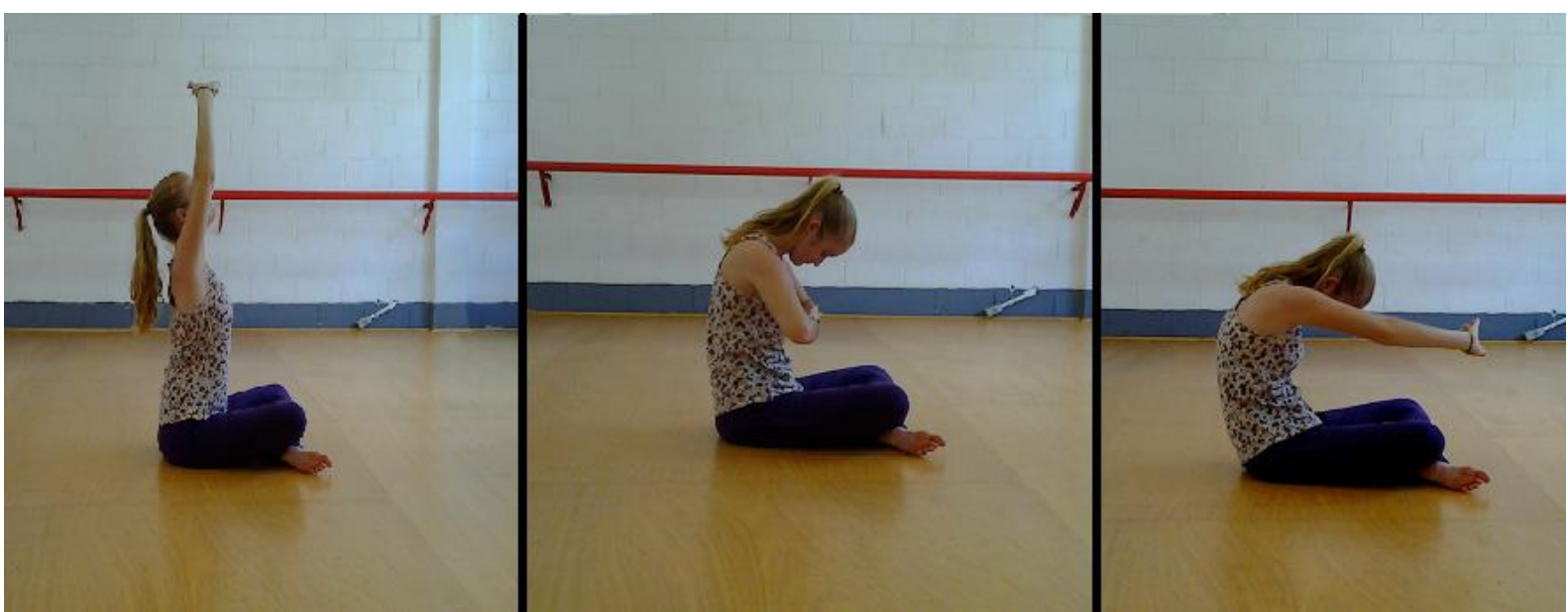

Figura 2 - Acervo pessoal

No entanto, Louppe (2012) destaca diferenças importantes entre as técnicas de Graham e Humphrey:

Os fundamentos da técnica de Graham são, portanto, extraídos de uma 'nova abordagem à fisicalidade a partir do processo da respiração'. A respiração intervém de maneira completamente diferente no trabalho de Doris Humphrey. A sua poética de alternância de estados, em que 0 movimento nasce da instabilidade entre queda e restabelecimento, faz intervir mais frequentemente as flutuações de peso. (LOUPPE, 2012, p. 9596).

Palavras-chave para a técnica de Humphrey e de seu discípulo José Limón, fall e recovery - isto é, a queda ou abandono do corpo à força da gravidade e sua recuperação e controle, respectivamente - são ações que decorrem das modulações entre respiração e peso, através das quais se articula permanentemente uma poética do peso (LOUPPE, 2012).

Assim, a presença de diferentes influências respiratórias produziu também variadas formas de experimentar os materiais selecionados: isolados, em suas possíveis combinações ou gerando uma matriz-síntese dos elementos testados que pôde ser investigada em suas propriedades e de forma flexível.

GERALDI, Silvia Maria; FERREIRA, Julia. Entre o pensar e o sentir: investigações sobre a influência da respiração na formação técnico-artística do bailarino contemporâneo. Revista da FUNDARTE, Montenegro, p.243-261, ano 19, ํo 37, Janeiro/Março.

Disponível em: http://.seer.fundarte.rs.gov.br/index.php/RevistadaFundarte/index> 30 de março de 2019. 


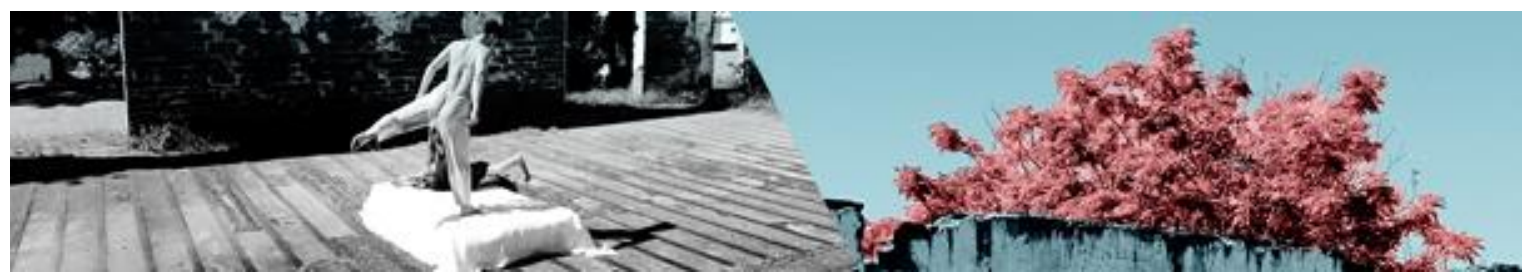

Essa primeira etapa da pesquisa foi, portanto, um processo contínuo e crescente de encontro com a técnica, composto por variados graus de aproximação entre o universo somático e a dança. Encontrar-se com a técnica significou aqui aventurar-se pelas ferramentas e pensamento que dão sustentação a esses campos específicos, mas também ao seu entrelaçamento.

Pode-se dizer que as observações mais amplas da Experiência Um relacionaram-se ao fortalecimento da imagem interna da coluna vertebral, resultando numa percepção mais clara de sua localização e movimentação, bem como de uma grande conexão entre todas as vértebras. O peso corporal foi outra qualidade marcante despertada pelas práticas, principalmente na bacia, evidenciando-se sua função como centro de gravidade e transporte de movimento.

No entanto, do ponto de vista técnico, a prática sistemática da respiração e sua reeducação podem trazer outros aprendizados ao corpo que dança. Feldenkrais (1994) elucida que o aperfeiçoamento de uma ação consiste em aprender a projetála mentalmente antes de executá-la no espaço, sem que haja, ainda, nenhuma interferência voluntária na respiração. Isso significa que a respiração deve agir independente da ação. Portanto, a atenção à respiração pode promover não somente o refinamento gradativo da própria ação de respirar, como também da percepção cinestésica e da própria habilidade de aprender; ou, nas palavras do próprio autor, "ao aprender a agir, deveremos nos sentir livres para prestar atenção ao que está acontecendo com o corpo, porque nesta situação, nossa mente estará clara e será fácil controlar a respiração; não há tensão gerada por esforço" (FELDENKRAIS, 1977, p. 82-83).

\section{Experiência Dois: respiração e acture}

A segunda parte da pesquisa concentrou-se no estudo das relações entre respiração e postura, embasando-se principalmente nos livros "Solte-se" (1992) e "Consciência pelo Movimento" (1977).

Da obra "Solte-se" foi selecionada a Lição 2 - Conforto na região inferior das costas, por propor a redução das tensões musculares nas costas, com consequente melhora do equilíbrio tônico entre o abdômen e a região da coluna lombar. A sessão

GERALDI, Silvia Maria; FERREIRA, Julia. Entre o pensar e o sentir: investigações sobre a influência da respiração na formação técnico-artística do bailarino contemporâneo. Revista da FUNDARTE, Montenegro, p.243-261, ano 19, oㅜ 37, Janeiro/Março.

Disponível em: http://.seer.fundarte.rs.gov.br/index.php/RevistadaFundarte/index> 30 de março de 2019. 


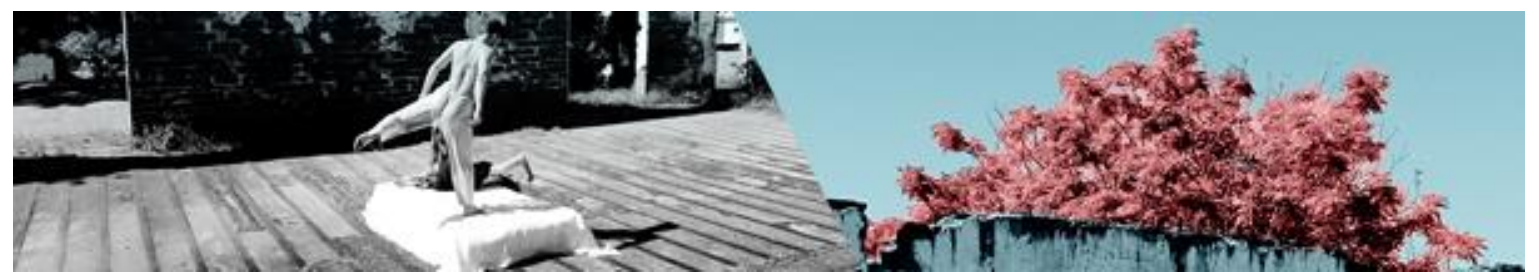

é realizada na posição deitada, com uma das mãos apoiada atrás da cabeça e a outra atrás do joelho. O movimento se concentra em levantar a cabeça, guiando o cotovelo ao encontro do joelho na expiração e, em seguida, retornar ao chão (ver Figura 3). Dependendo da posição das mãos, o movimento no tronco pode ser homolateral ou cruzado.

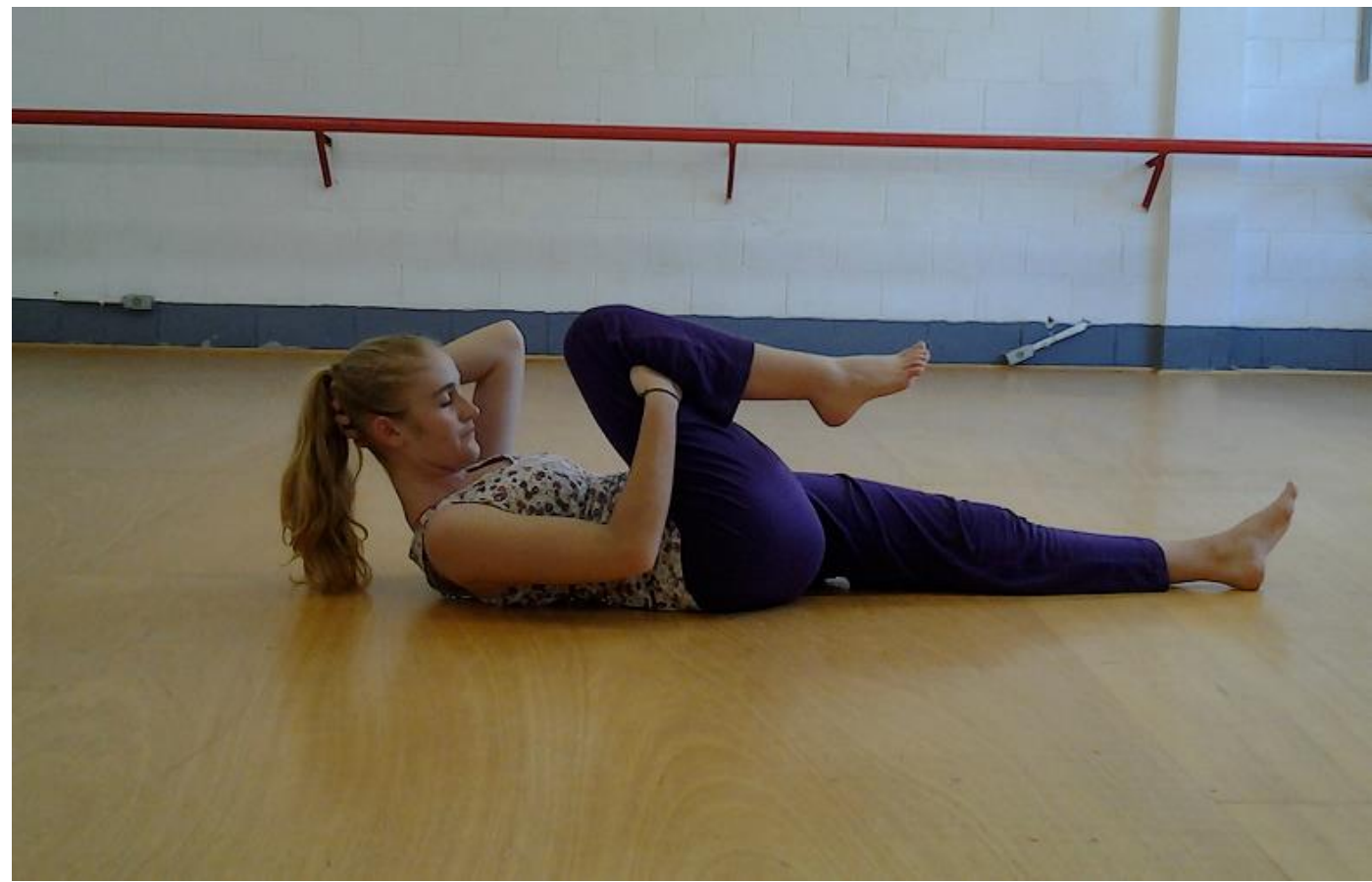

Figura 3 - Acervo pessoal

Um princípio básico da metodologia de Feldenkrais é que cada movimento deve ser leve, pequeno e realizado lentamente, de forma a reduzir o esforço ao mínimo e, em consequência, aumentar a sensibilidade cinestésica. Também a expiração deve ser feita a cada movimento, possibilitando, a exemplo da lição acima, o acionamento da cabeça em conjunto com o esterno que, deslizando para baixo, facilita a sustentação das vértebras cervicais, impedindo-as de serem esmagadas.

Em toda a sua obra, Feldenkrais (1977) alerta o leitor sobre a íntima ligação entre respiração e postura, e afirma que uma respiração internamente desorganizada pode vir a prejudicar a qualidade de vida e a própria postura corporal:

GERALDI, Silvia Maria; FERREIRA, Julia. Entre o pensar e o sentir: investigações sobre a influência da respiração na formação técnico-artística do bailarino contemporâneo. Revista da FUNDARTE, Montenegro, p.243-261, ano 19, ํo 37, Janeiro/Março.

Disponível em: http://.seer.fundarte.rs.gov.br/index.php/RevistadaFundarte/index> 30 de março de 2019. 


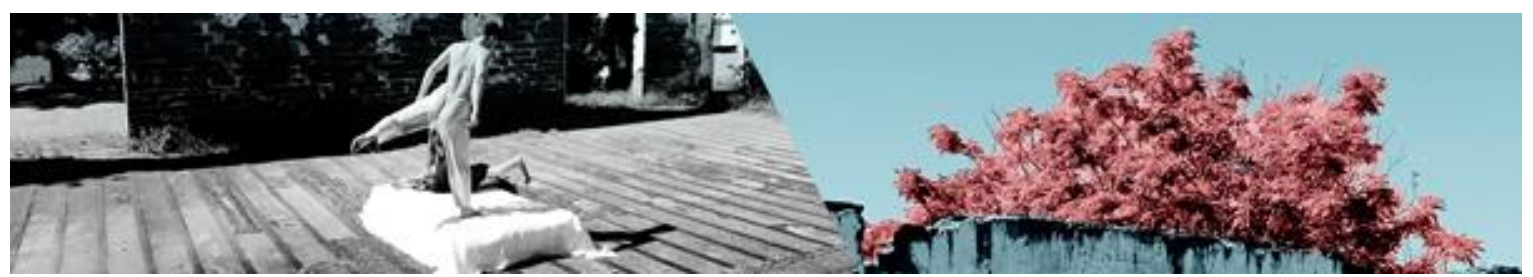

A maior parte dos músculos do sistema respiratório está ligada às vértebras lombares e cervicais e a respiração afeta, portanto, a estabilidade da postura e da espinha e, reciprocamente, a posição da espinha afeta a qualidade e velocidade da respiração. Portanto, boa respiração significa também boa postura, tanto quanto boa postura significa boa respiração. (FELDENKRAIS, 1997, p. 213).

Feldenkrais (1994) faz também uma distinção importante entre postura e posição. Enquanto a posição relaciona-se à localização e configuração dos diversos segmentos do corpo, sugerindo imobilidade, a postura é um termo dinâmico relacionado à ação e ao uso total do self para alcançar e manter determinada posição. Ela está relacionada à maneira como os indivíduos utilizam "o conjunto cérebrossomático; isto é, o modo como as emoções, a motivação, a direção e a execução do ato são organizadas durante a sua realização" (FELDENKRAIS, 1994, p. 65). Acture é o termo adotado por ele para definir postura, síntese das palavras action (ação) e posture (postura), indicando sua relação intrínseca.

Do livro "Consciência pelo Movimento" (1977), foram selecionadas as Lições 1 ( $O$ que é uma boa postura?) e 3 (Algumas propriedades fundamentais do movimento). A primeira discute aspectos dinâmicos da postura e do equilíbrio, abordando, na teoria e na prática, os principais conceitos relacionados ao tema dentro do sistema proposto por Feldenkrais. As sessões práticas envolvem os movimentos de balanço nas posições de pé e sentada, seguidas do estudo do elo dinâmico entre estar sentado e de pé. Elas vão mobilizando, de forma gradual, uma adequada organização postural na posição de pé, de modo que o esforço muscular seja mínimo. Os movimentos pendulares leves para frente e trás, para um lado e outro, ou em círculos, buscam promover a percepção da organização de todos os músculos do peito, incluindo ombros, clavícula, nuca, costelas e diafragma, diminuindo-Ihes a tensão. Despertam também para a importância do relacionamento contínuo entre respiração e as trocas de direção. Por sua vez, o movimento de levantar-se de uma cadeira busca levar o praticante a perceber que uma maior eficiência pode ser alcançada quando se separa a ação da intenção, isto é, quando a atenção está centrada nos meios pelos quais a ação se realiza (processo de

GERALDI, Silvia Maria; FERREIRA, Julia. Entre o pensar e o sentir: investigações sobre a influência da respiração na formação técnico-artística do bailarino contemporâneo. Revista da FUNDARTE, Montenegro, p.243-261, ano 19, oㅜ 37, Janeiro/Março.

Disponível em: http://.seer.fundarte.rs.gov.br/index.php/RevistadaFundarte/index> 30 de março de 2019. 


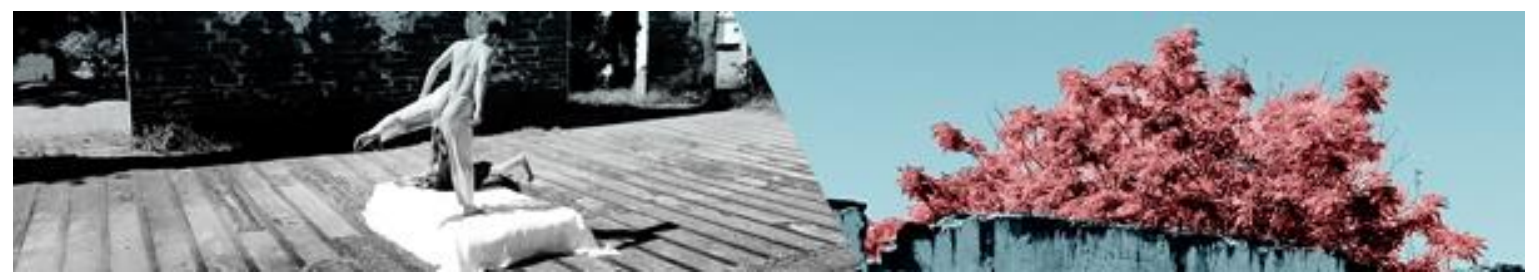

autoconhecimento) e não nos objetivos a serem alcançados (ficar de pé). A respiração tem aqui importante papel de identificação dos esforços supérfluos investidos na ação: à medida que o sentimento de facilidade progride com a prática, a tendência instintiva de segurar a respiração desaparece.

No capítulo 3, a sessão é realizada inteiramente na posição deitada, de costas ou de barriga para baixo. O objetivo principal é reconhecer como a mudança de tônus dos músculos (seu estado de contração) pode ser controlada tanto por meio da observação e compreensão dos esforços supérfluos na ação quanto através da coordenação entre respiração e movimento. À medida que se elimina o trabalho latente dos músculos, fica perceptível a ampliação do contato do corpo com o solo, particularmente ao longo da coluna, criando um estado de segurança diferenciado para que os movimentos aconteçam. Conforme esclarece a estudiosa somática Marisa Lambert:

[...] a descoberta do suporte muscular interno traz a sensação de inteireza e conforto ao mover-se, uma vez que se pode relaxar o peso e a tensão dos tecidos mais externos do corpo e se entregar à trama de conexões profundas, responsáveis também por nutrir o corpo com um sentido de propósito e vitalidade. Afinar-se com o centro torna o sujeito mais disponível para relacionar-se com 0 entorno. Uma prontidão que se origina na experiência de centramento. (LAMBERT, 2010, p. 96).

Essa sensação de centramento resulta também de uma melhor organização das linhas de ação corporal, deixando que a força principal seja realizada pelos músculos pélvicos, maiores e mais fortes, e que esta seja transmitida pelos ossos até os membros sem muita perda de potência no caminho (FELDENKRAIS, 1977).

Do mesmo modo que na primeira etapa da pesquisa, as sessões somáticas deram subsídio para relacionar o tema da postura/respiração com matrizes desenvolvidas dentro das aulas de dança da graduação. Os desafios motores foram coletados da disciplina de técnica em andamento naquele semestre, sobretudo por sua semelhança com os estudos respiratórios e tônico-gravitacionais que vinham sendo realizados. Nessas aulas, o fluxo (flow) foi um elemento em evidência, explorado a partir de variações de movimento bastante elaboradas e tendo sempre como suporte a respiração. Em geral, cada aula partia de um encontro com o centro

GERALDI, Silvia Maria; FERREIRA, Julia. Entre o pensar e o sentir: investigações sobre a influência da respiração na formação técnico-artística do bailarino contemporâneo. Revista da FUNDARTE, Montenegro, p.243-261, ano 19, ํo 37, Janeiro/Março.

Disponível em: http://.seer.fundarte.rs.gov.br/index.php/RevistadaFundarte/index> 30 de março de 2019. 


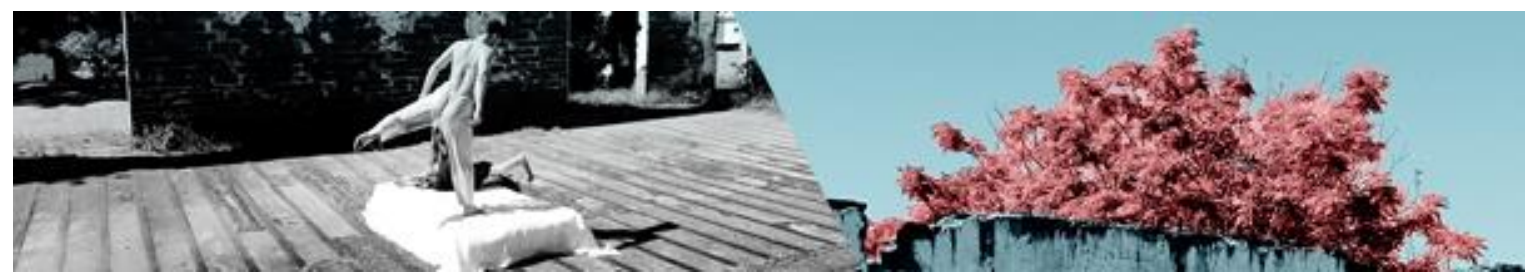

do corpo, seguido por um momento de expansão energética que o conectava às extremidades sem que houvesse a perda da maleabilidade alcançada no momento inicial. A respiração era utilizada como recurso para a instalação de uma concentração ativa, semelhante a um estado meditativo, no qual a mente podia se acalmar, focando-se no presente. O contato com esse estado excepcional tinha como fim permitir uma maior entrega do corpo ao movimento, de modo a deixá-lo resolver, por sua própria inteligência, os caminhos que aparecessem durante a realização da variação. A respiração era também um meio de se atingir a qualidade de fluência desejada durante a realização da combinação dos movimentos.

Para os laboratórios individuais, foram testados exercícios bastante explorados em aula, nos quais a ênfase era o trabalho de solo com demandas de fluxo contínuo e inversões da relação cabeça-bacia. A experiência deu origem a uma partitura mais elaborada, criada da combinação entre recursos somáticos e movimento dançado, que incluía rolamentos, deslizes, mobilidade da coluna, mudança de apoios e níveis, quedas e recuperações. Para a execução, lançou-se mão de duas provocações fornecidas pela professora nas experiências de aula: a sustentação do fluxo livre, acrescida da sensação de se estar no mesmo plano que o chão (e não acima dele). O desafio dado ao corpo, portanto, era buscar suavizar suas quinas para que se conseguisse criar uma relação de continuidade fluida com o solo, sobre o qual o corpo deveria passar, mas não parar.

Compreendeu-se, durante a prática laboratorial, que a qualidade corporal exigida para que ocorresse esse deslizamento contínuo do corpo pelo espaço, fosse no chão ou nos diferentes níveis, ligava-se também às relações dinâmicas entre esqueleto, músculos e gravidade - àquilo que Feldenkrais (1977) entende por ação eficiente. Segundo ele, numa postura eficiente, o esqueleto tem como função colocar-nos na posição vertical, contrapondo-se à ação da gravidade sem qualquer gasto extra de energia. Já os músculos ficam livres para a realização do movimento. De outro modo, quando a musculatura realiza a sustentação do corpo, ela está executando parte do trabalho da estrutura esquelética:

GERALDI, Silvia Maria; FERREIRA, Julia. Entre o pensar e o sentir: investigações sobre a influência da respiração na formação técnico-artística do bailarino contemporâneo. Revista da FUNDARTE, Montenegro, p.243-261, ano 19, ํo 37, Janeiro/Março.

Disponível em: http://.seer.fundarte.rs.gov.br/index.php/RevistadaFundarte/index> 30 de março de 2019. 


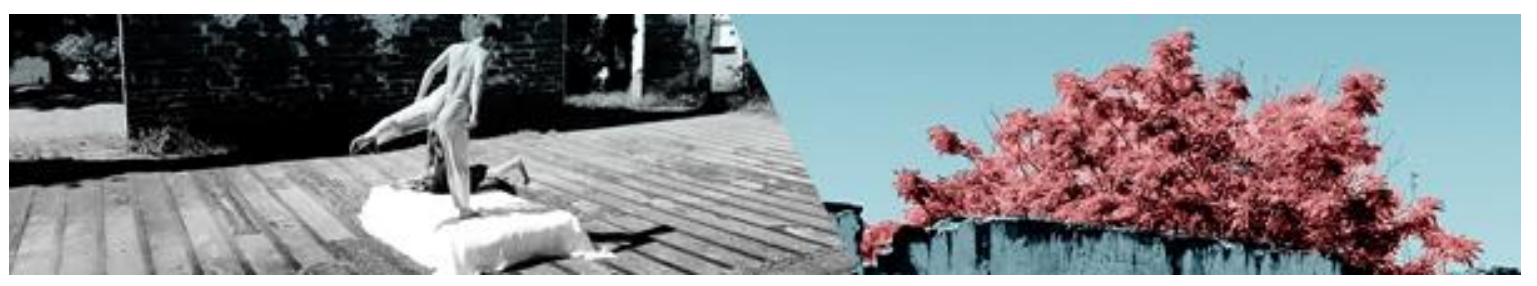

Se, de outra parte, os músculos têm que realizar o trabalho do esqueleto, eles não apenas usam desnecessariamente energia, como são impedidos de realizar sua função principal que é de mudar a posição do corpo ou de suas partes, isto é, produzir movimento. (FELDENKRAIS, 1977, p. 93).

Se o corpo não estiver em conflito com essa lei fundamental, a ação conjunta entre musculatura e estrutura óssea fará com que o mesmo encontre o chão suavemente, evitando que desabe ou realize excessivo esforço para produzir movimento. Acrescente-se a isso o uso correto dos músculos pélvicos para o trabalho pesado de mover o corpo e a transmissão do esforço muscular através dos ossos, conforme citado acima. Feldenkrais (1977) ainda destaca que quando um esqueleto se move de uma posição a outra, a via de ação ideal é o caminho através do qual ele poderia mover-se se não existissem músculos, apenas ligamentos conectando os ossos.

A sensação de facilidade, leveza e prazer que acompanham uma sessão de movimento é outro excelente termômetro para se medir a qualidade do que foi realizado. O uso do tempo e a atenção à respiração são ferramentas que afetam essa percepção. Quando Feldenkrais (1977) insiste na lentidão é para que o movimento possa se ajustar continuamente ao ritmo respiratório pessoal. Conforme a ação se torne mais organizada, respiração e movimento se ajustarão organicamente, podendo-se acentuar, variar ou atenuar a velocidade sem que haja interferência direta na ação.

Resumidamente, pode-se dizer que o contrato espontâneo entre a acture e a respiração foi, nessa segunda etapa da pesquisa, a chave para o reconhecimento do que Feldenkrais chama de boa ação.

\section{Pensar e sentir como prática de pesquisa}

Um dos atributos do sistema desenvolvido por Feldenkrais, comum também a outras abordagens somáticas, é a não separação entre pensar, agir e sentir. Ao aprender o método, aprende-se por extensão a agir enquanto se pensa, a compreender enquanto se faz, a sentir para discriminar. Uma vez assimilada, a habilidade pode ser transferida para a ação do(a) pesquisador(a) no sentido de auxiliá-lo(a) a estreitar os vínculos entre pensamento e ação, entre teoria e prática -

GERALDI, Silvia Maria; FERREIRA, Julia. Entre o pensar e o sentir: investigações sobre a influência da respiração na formação técnico-artística do bailarino contemporâneo. Revista da FUNDARTE, Montenegro, p.243-261, ano 19, oㅜ 37, Janeiro/Março.

Disponível em: http://.seer.fundarte.rs.gov.br/index.php/RevistadaFundarte/index> 30 de março de 2019. 


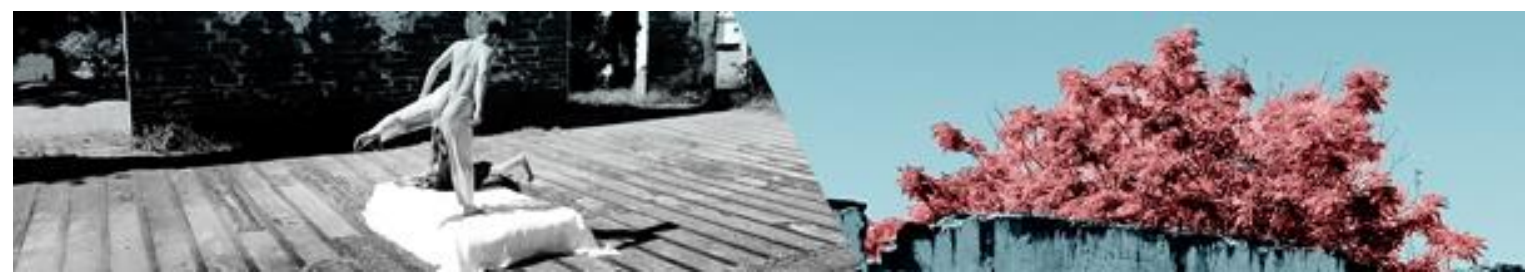

tarefa nem sempre fácil de ser realizada, sobretudo para investigadores em início de trajetória.

Considera-se que essa tenha sido uma conquista real dessa pesquisa. Após ter passado pela experiência no corpo, a releitura do livro "Consciência pelo Movimento" (1977) proporcionou à pesquisadora/estudante uma compreensão muito mais clara das ligações entre processo respiratório e postura. Muitos dos conhecimentos, revistos à luz das práticas corporais da pesquisa, fizeram um sentido singular, permitindo que a conceituação e discussão teórica fossem construídas a partir do processo prático, conforme desenho de pesquisa proposto.

Os laboratórios e as aulas realizadas durante o estudo construíram um modo diferente de pensar o trabalho corporal e o corpo que dança, orientando a aprendizagem para o "desenvolvimento de uma autoridade interior concernente à capacidade de tomar decisões baseadas em discriminações sensórias que acentuem a singularidade do corpo" (FORTIN; VIEIRA; TREMBLAY, 2010, p. 75).

Destaca-se que o entendimento prático dos conceitos, relações e dinâmicas aqui discutidos demanda tempo e aprimoramento da atenção. Para compreender um movimento é preciso afinar não apenas a capacidade de sentir, mas também a capacidade de diferenciar o que se sente. Feldenkrais (1977, p. 83) ilustra bem essa questão com o seguinte exemplo: "Se eu levanto uma barra de ferro, não sentirei a diferença se uma mosca pousar nela. De outra parte, se estou segurando uma pena, sentirei distintamente a diferença, se uma mosca assentar nela". Isso sugere que quanto mais leve o estímulo, mais fina a discriminação.

Os laboratórios se tornaram também um espaço de aprofundamento técnico/somático do material coletado, produzido ou proveniente das pesquisas teóricas. O registro escrito e visual das experiências corporais tornou-se um instrumento importante para o aprofundamento das práticas e também para comunicação do processo, permitindo seu compartilhamento com outros pesquisadores do movimento que tenham interesse pelo tema respiração.

GERALDI, Silvia Maria; FERREIRA, Julia. Entre o pensar e o sentir: investigações sobre a influência da respiração na formação técnico-artística do bailarino contemporâneo. Revista da FUNDARTE, Montenegro, p.243-261, ano 19, ํo 37, Janeiro/Março.

Disponível em: http://.seer.fundarte.rs.gov.br/index.php/RevistadaFundarte/index> 30 de março de 2019. 


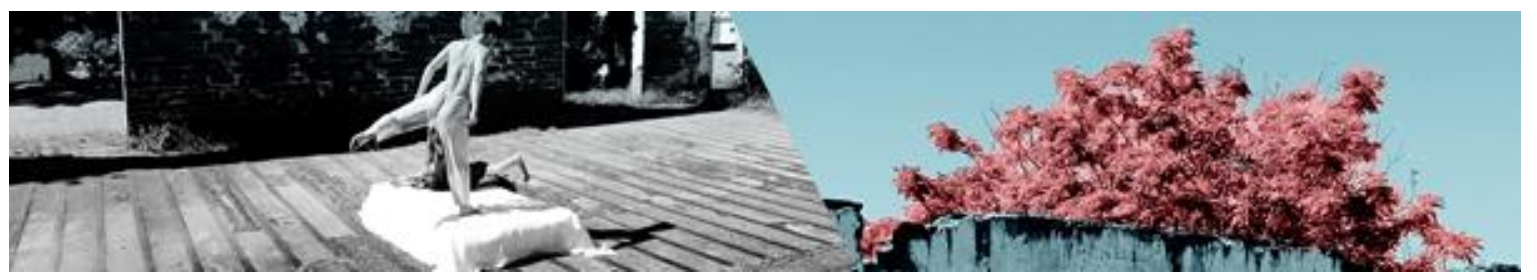

\section{Referências:}

BARDET, Marie. A Atenção através do Movimento: o método Feldenkrais como disparador de um pensamento sobre a atenção. Revista Brasileira de Estudos da Presença, Porto Alegre, v. 5, n. 1, p. 191-205, jan./abr. 2015. Disponível em: https://seer.ufrgs.br/presenca/issue/view/2365/showToc. Acesso em: 25 nov. 2016.

CAVRELL, Holly Elizabeth. Dando Corpo à História - Tese (Doutorado em Artes) Instituto de Artes - Universidade Estadual de Campinas, São Paulo, 2010.

FELDENKRAIS, Moshe. Consciência pelo Movimento. 4. ed. São Paulo: Summus, 1977.

O poder da autotransformação: a dinâmica do corpo e da mente. Tradução de Denise Maria Bolanho. São Paulo: Summus, 1994.

FORTIN, Sylvie; VIEIRA, Adriane; TREMBLAY, Martyne. A experiência de discursos na dança e na educação Somática. Movimento, Porto Alegre, v. 16, n. 02, p. 71-91, abr./jun. 2010. Disponível em: https://seer.ufrgs.br/Movimento/article/view/10243/0. Acesso em: 03 abr. 2016.

FORTIN, Sylvie. Contribuições possíveis da etnografia e da autoetnografia para a pesquisa na prática artística. Revista Cena - Periódico do Programa de PósGraduação em Artes Cênicas, Instituto de Artes, Universidade Federal do Rio Grande do Sul, n. 7, p. 77-88, 2010. Disponível em: https://seer.ufrgs.br/cena/article/view/11961/7154. Acesso em: 10 fev. 2016.

LAMBERT, Marisa Martins. Expressividade Cênica pelo Fluxo Percepção/Ação: O Sistema Laban/Bartenieff no desenvolvimento somático e na criação em dança. Tese (Doutorado em Artes) - Instituto de Artes - Universidade Estadual de Campinas, São Paulo, 2010.

LEAL, Patrícia Garcia. As relações entre a respiração e o movimento expressivo no trabalho de chão da técnica de Martha Graham. Campinas. Dissertação (Mestrado em Artes) - Institutos de Artes - Universidade Estadual de Campinas, São Paulo, 2000.

LOUPPE, Laurence. Poética da dança contemporânea. Lisboa: Orfeu Negro, 2012.

SUQUET, Annie. Cenas, O corpo dançante: um laboratório de percepção. In: COURTINE, Jean-Jacques (Org.). História do corpo: as mutações do olhar. Século XX. Petrópolis: Vozes, 2008. v. 3, p. 513.

ZEMACH-BERSIN, D.; ZEMACH-BERSIN, K.; REESE, M. Solte-se: método de relaxamento para a saúde e a boa forma. Tradução: Denise Bolanho; revisão técnica: Mathilda Yahkni. São Paulo, Summus, 1992.

GERALDI, Silvia Maria; FERREIRA, Julia. Entre o pensar e o sentir: investigações sobre a influência da respiração na formação técnico-artística do bailarino contemporâneo. Revista da FUNDARTE, Montenegro, p.243-261, ano 19, ํo 37, Janeiro/Março.

Disponível em: http://.seer.fundarte.rs.gov.br/index.php/RevistadaFundarte/index> 30 de março de 2019. 